\title{
CELL-WALL COMPOSITION AND POLYSACCHARIDE SYNTHASE ACTIVITY CHANGES FOLLOWING PHOTOINDUCTION IN TRICHODERMA VIRIDE*
}

\author{
M. NEMČOVIČ and V. FARKAš ${ }^{* *}$ \\ Institute of Chemistry, Slovak Academy of Sciences, Dúbravská cesta 9, 84238 Bratislava, Slovakia
}

(Received: August 31, 2000; accepted: October 5, 2000)

\begin{abstract}
The differentiation and metabolism in the soil-borne saprophytic deuteromycete Trichoderma viride are subject to control by light. We have investigated the effect of illumination of mycelia on the activities of cell-wall synthesizing enzymes $\beta$-1,3-glucan synthase and chitin synthase and on the composition of cell walls. After 10 min illumination of dark-grown mycelia with white fluorescent light at 600 lx, a gradual rise in specific activity of membrane-bound enzymes $\beta$-1,3-glucan synthase by about $130 \%$ and a decrease in specific activity of chitin synthase by about $50 \%$ in relation to the dark control were observed. The changes in enzyme activities were caused by de novo synthesis of corresponding polysaccharide synthases(s) and/or their regulatory components since they were not observed when protein synthesis was blocked with $50 \mu \mathrm{g} / \mathrm{ml}$ cycloheximide. The content of $\beta-1,3$-glucan in the cell walls of illuminated mycelia has increased by $35-50 \%$ in comparison to the dark control while the content of chitin remained practically unchanged.
\end{abstract}

Keywords: cell-wall - glucan - chitin - conidiation - photoinduction - Trichoderma

\section{INTRODUCTION}

Trichoderma viride belongs to those fungi whose development is strongly influenced by light. Immediately after reception of the light signal, the mycelium starts a series of biochemical, physiological changes followed by the formation of aerial hyphae and phialides and ending with the formation of brown or dark-green conidia on the surface of colonies at what had been the colony perimeter at the time of irradiation [reviewed in $2,3,10]$. Since in fungi, the shape of the cell is determined by the shape of the cell wall, it is conceivable that morphological changes accompanying development must be controlled by regulation of activities of the enzymes involved in the biosynthesis of the cell wall. The aim of the present study was to investigate the

\footnotetext{
*Dedicated to Professor Lajos Ferenczy on the occasion of his 70th birthday.

**Corresponding author; e-mail: chemvfar@savba.sk

Abbreviations: PMSF, phenylmethylsulfonyl fluoride; BSA, bovine serum albumin; EGTA, ethylene
} glycol-bis( $\beta$-aminoethyl ether); N,N,N',N'-tetraacetic acid; DTT, dithiothreitol. 
effects of illumination on the activities of the two principal cell-wall synthesizing enzymes $\beta$-1,3-glucan synthase and chitin synthase in Trichoderma viride and to correlate them with changes in the carbohydrate composition of the cell walls.

\section{MATERIALS AND METHODS}

\section{Chemicals}

UDP-[U-14C]-glucose, specific radioactivity $5.06 \mathrm{MBq} \mathrm{mmol}^{-1}$ was from Nycom, s. r. o. (Prague, Czech Republic). UDP-[U- $\left.{ }^{14} \mathrm{C}\right] \mathrm{N}$-acetyl-D-glucosamine, specific radioactivity 9.6 MBq mmol-1 was purchased from Amersham (UK). Serratia marcescens chitinase, GTP $\gamma \mathrm{S}$ and cycloheximide were from Sigma Chemical Co. (St. Louis, USA). Zymolyase 100T ( $\beta$-1,3-glucanase) was from Seikagaku (Japan). Other chemicals used were of analytical grade from various commercial sources.

\section{Microorganism and culture conditions}

Trichoderma viride (Persoon ex S. F. Gray), strain no. CCM F-534 from the Czech Collection of Microorganisms (Brno, Czech Republic) was used. The basal medium for fungus maintenance was Czapek-Dox agar. For experiments, $50 \mathrm{ml}$ Czapek-Dox medium containing $2 \%$ glucose as the carbon source were inoculated with $1-2 \times 10^{6}$ freshly harvested spores. The flasks were wrapped in aluminum foils to protect them from the light and incubated on a gyratory shaker at $28^{\circ} \mathrm{C}$ for $36 \mathrm{~h}$ to obtain young mycelia. The suspensions of grown mycelia were then poured into Petri dishes (16 $\mathrm{cm}$ in diameter) so as to cover the whole surface of the dish with a thin layer of the culture. After 30 min equilibration at $28-30{ }^{\circ} \mathrm{C}$ in the dark, some of the Petri dishes were illuminated for different time periods with white fluorescent lamp at $600 \mathrm{~lx}$ illuminance. The dishes were then incubated at $30{ }^{\circ} \mathrm{C}$ in the dark for different time periods. All manipulations with mycelia were realized under red safelight. Cycloheximide, when applied, was added to Erlenmayer flasks at final concentration $50 \mu \mathrm{g} \mathrm{ml}^{-1}$ 10 minutes before transferring the mycelia to Petri dishes.

\section{Membrane preparations and enzyme assays}

The mycelia after different treatments were collected by centrifugation and twice washed with cold distilled water. All subsequent operations were performed at $0-4$ ${ }^{\circ} \mathrm{C}$. The pellets were suspended in basal buffer $(50 \mathrm{mM}$ Tris chloride, $\mathrm{pH} 7.5$, containing $1 \mathrm{mM}$ DTT). For glucan synthase work, the basal buffer was supplemented with $1 \mathrm{mM}$ EGTA plus $1 \mathrm{mM}$ PMSF and for chitin synthase with $1 \mathrm{mM} \mathrm{MgSO}_{4}$. The mycelium was broken in cooled rotary disintegrator with glass beads and the membrane fractions were isolated as described elsewhere [12]. Final membrane pellets 
were resuspended in the appropriately supplemented (see above) basal buffer containing $33 \%$ glycerol $(0.2$ vol. of the buffer per $1 \mathrm{~g}$ wet wt. of the starting mycelial biomass) and immediately used in the assays. Protein was determined by the Lowry method [13] using bovine serum albumin (BSA) as the standard.

Glucan synthase was assayed as described previously [12], except that Brij 35 was omitted from the assay mixture and the incubation was carried out at $30^{\circ} \mathrm{C}$ for 30 min. For chitin synthase assay, the $50 \mu 1$ reaction mixture contained $0.1 \mathrm{M}$ Tris-HCl buffer, $\mathrm{pH}$ 7.2, $10 \mathrm{mM} \mathrm{Mg}{ }^{2+}$ acetate, $0.4 \mathrm{M} \mathrm{N}$-acetyl-D-glucosamine, $1 \mathrm{mM}$ UDP$\left[\mathrm{U}-{ }^{14} \mathrm{C}\right] \mathrm{N}$-acetyl-D-glucosamine (specific radioactivity $18 \mathrm{~Bq} \mathrm{nmol}^{-1}$ ) and $0.04-0.07$ $\mathrm{mg}$ membrane protein. Since a portion of fungal chitin synthase exists in the cells as proteolytically activable zymogen $[4,5]$, in a parallel series of the assays the membranes were preincubated with $10 \mu \mathrm{g}$ of trypsin in the absence of the substrate at 30 ${ }^{\circ} \mathrm{C}$ for $10 \mathrm{~min}$ and the activation was stopped by the addition of $15 \mu \mathrm{g}$ of soybean trypsin inhibitor. The assay was initiated by the addition of $5 \mu 1$ of $10 \mathrm{mM}$ UDP-[U$\left.{ }^{14} \mathrm{C}\right] \mathrm{N}$-acetyl-D-glucosamine and the incubation was carried out for $30 \mathrm{~min}$ at $30{ }^{\circ} \mathrm{C}$. The identity of the reaction products was confirmed by their susceptibility to hydrolysis with $\beta$-1,3-glucanase (Zymolyase 100T) and chitinase.

\section{Cell wall analysis}

The cell walls were isolated by mechanical breakage of the mycelia as described above and centrifuging the homogenate at $1,500 \times \mathrm{g}$ for $10 \mathrm{~min}$. The pellets were washed about 20 times with ice-cold $1 \mathrm{M} \mathrm{NaCl}$. The purity of the cell wall preparation was controlled by phase-contrast microscopy and by monitoring the presence of UV-absorbing (260-280 nm) material in the washings. Finally, the cell walls were washed three times with water and lyophillized. For glucan determination, $10 \mathrm{mg}$ of the dry walls were wetted in $0.2 \mathrm{ml} 70 \%(\mathrm{w} / \mathrm{v}) \mathrm{H}_{2} \mathrm{SO}_{4}$ and allowed to stand at $4{ }^{\circ} \mathrm{C}$ for $16 \mathrm{~h}$. Then, $1.8 \mathrm{ml}$ of distilled water were added, the tubes were sealed and heated at $100{ }^{\circ} \mathrm{C}$ for $8 \mathrm{~h}$. The hydrolysate was neutralized with $2 \mathrm{M} \mathrm{NaOH}$ and the volume was adjusted with water to $10 \mathrm{ml}$. Glucose in the hydrolysate was determined using glucose oxidase-peroxidase kit (Lachema, Czech Republic). For chitin determination, $10 \mathrm{mg}$ of dry cell walls were deproteinized by incubation with $2 \mathrm{ml}$ of 0.1 $\mathrm{M} \mathrm{NaOH}$ at room temperature for $20 \mathrm{~h}$. The suspensions were then centrifuged at $5,000 \times g$ for $15 \mathrm{~min}$ and the sediments were washed twice with $1 \mathrm{M}$ acetic acid and five times with water. The pellets were suspended in $2 \mathrm{ml}$ of $6 \mathrm{M} \mathrm{HCl}$ and the sealed tubes were heated at $105^{\circ} \mathrm{C}$ for $6 \mathrm{~h}$. After neutralization with $3 \mathrm{M} \mathrm{NaOH}$ and adjusting the volume to $10 \mathrm{ml}$, the aminosugars in the hydrolysate were determined with Ehrlich reagent [7]. 


\section{Reproducibility of results}

All experiments were performed for 3 to 6 times and the assays of enzyme activities were done in triplicates. The analysis of the cell walls was done with samples prepared from three independent experiments. Although the absolute values differed from experiment to experiment, generally a good reproducibility was obtained in all cases.

\section{RESULTS AND DISCUSSION}

Differentiation in fungi is inseparable from changes in cellular morphology which, in turn, is largely determined by activities of the enzymes involved in the formation of the cell wall. In spite of this direct relationship, reports concerning the effect of light on cell wall structure and biosynthesis during photoregulated development in fungi are relatively scarce. One of the first studies on this subject [11] described the stimulatory effect of light on the activity of chitin synthase in crude homogenates from Phycomyces blakesleanus. The stimulation by light was not observed in the isolated plasma-membrane fractions, indicating that the effect of light on the activity of the enzyme was indirect. The experiments with crude homogenates from Phycomyces were later confirmed by Herrera-Estrella et al. [9]. It has been proposed that cAMP could serve as the second messenger and activate chitin synthesis and degradation of glycogen [15]. Fiema [8] has observed that light-dependent formation of conidiophores in Aspergillus giganteus is associated with increased chitin contents in the cell walls.

In Trichoderma viride, the first morphological changes appear about $4 \mathrm{~h}$ after illumination when the formation of aerial mycelia takes place, followed by development

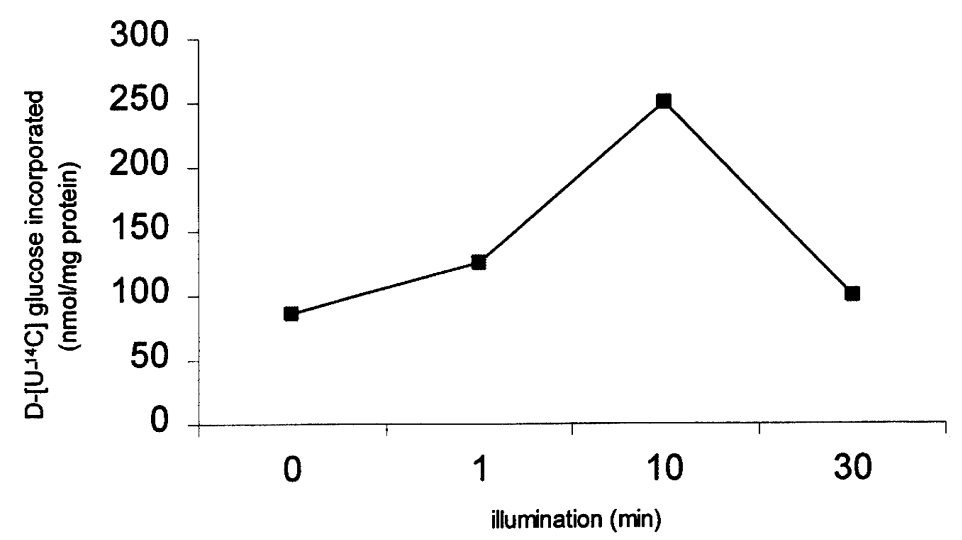

Fig. 1. Changes in specific activity of $\beta$-1,3-glucan synthase as the function of the duration of illumination. Dark-grown mycelia of Trichoderma viride were illuminated at $600 \mathrm{~lx}$ with white fluorescent light for various time intervals followed by $30 \mathrm{~min}$ incubation in the dark before extraction 


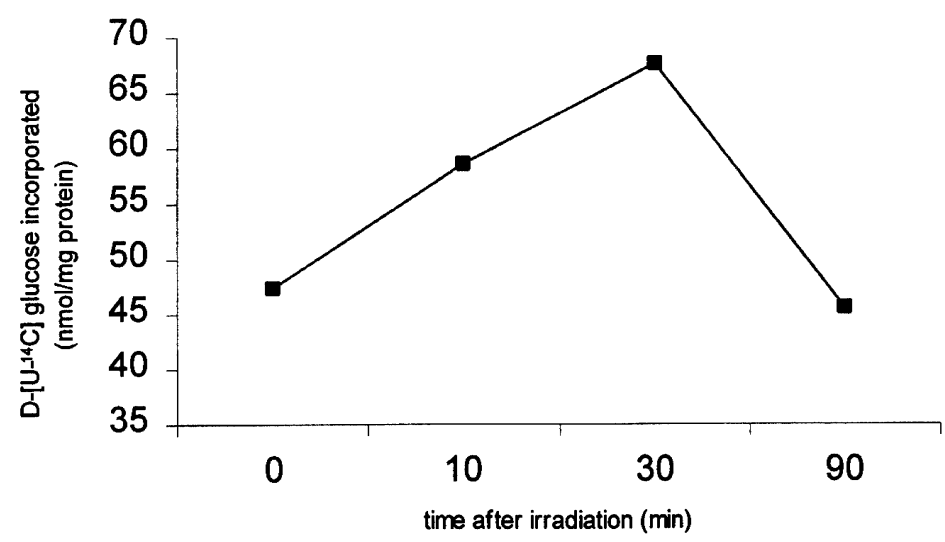

Fig. 2. Changes in $\beta$-1,3-glucan synthase activity with time following 10 min irradiation of mycelia of T. viride with white fluorescent light at $600 \mathrm{~lx}$

of conidia-bearing structures and formation of conidia approximately 16 to $24 \mathrm{~h}$ after irradiation $[2,3]$. Our results show that the illumination of mycelia affected the activities of both key enzymes involved in cell wall biosynthesis: $\beta$-1,3-glucan synthase (GS) and chitin synthase (CHS). The effect of illumination on these enzyme activities depended, to a certain extent, on the duration of illumination (Fig. 1) and also on the time which elapsed from the exposure of the mycelia to light (Fig. 2). The activation of glucan synthase by illumination depended on undisturbed protein synthesis since in the presence of $50 \mu \mathrm{g} / \mathrm{ml}$ no rise in the enzyme activity was observed (Fig. 2).

From the yeast model is known that fungal GS consists of two principal components: a catalytic subunit encoded by FKS1 and/or FKS2 genes and a regulatory, GTP-binding subunit encoded by RHO1 $[6,14]$. To ascertain which of these two activities were more affected by light, we performed GS assays both in the presence, and in the absence, of GTP $\gamma \mathrm{S}$. It was found that the increase in GS activity caused by light was more pronounced when the assays were performed in the presence of GTP $\gamma \mathrm{S}$ than in its absence (Table 1). This could be interpreted as meaning that light predominantly affected the synthesis of the Rholp which directly interacts with GTP $\gamma \mathrm{S}$.

On the other hand, a negative effect of illumination was observed on the activity of chitin synthase: in this case the enzymes isolated from the illuminated mycelia exhibited lower specific activity than those from the dark controls (Table 1). The diminished activity of CHS after illumination indicates a gradual decay of the enzyme since the extent of activity decrease was roughly the same in trypsinized as well as in non-trypsinized membranes and was not depending on protein synthesis.

The differences in the enzyme activities caused by illumination were reflected to some extent also in the chemical composition of the cell walls (Table 2). In accordance with the found increase in GS activity, the content of $\beta$-glucan in the cell walls 
Table 1

Effect of illumination of mycelia of Trichoderma viride on glucan synthase (GS) and chitin synthase (CHS) activities

\begin{tabular}{cc}
\hline Enzyme and assay conditions & Activity \\
$(\% \text { of the dark control })^{\mathrm{a}}$
\end{tabular}

GS from normal cells:

$\begin{array}{ll}+ \text { GTP } \gamma S & 230 \pm 96(6) \\ - \text { GTP } \gamma S & 164 \pm 42(6)\end{array}$

GS from cells treated with cycloheximide:

$\begin{array}{ll}+ \text { GTP } \gamma \text { S } & 65 \pm 17(3) \\ - \text { GTP } \gamma \text { S } & 71 \pm 18(3)\end{array}$

CHS from normal cells:

$\begin{array}{ll}- \text { trypsin } & 54 \pm 34(6) \\ + \text { trypsin } & 48 \pm 18(6)\end{array}$

CHS from cells treated with cycloheximide:

$$
\begin{array}{ll}
- \text { trypsin } & 64 \pm 4(3) \\
+ \text { trypsin } & 56 \pm 7(3)
\end{array}
$$

${ }^{a}$ The absolute values for controls varied from experiment to experiment, but were, on average, 32 nmoles of D-[U- $\left.{ }^{14} \mathrm{C}\right]$ glucose and/or 27 nmoles of D-[U$\left.{ }^{14} \mathrm{C}\right] \mathrm{GlcNAc}$ incorporated into TCA insoluble fraction from their respective nucleotide donors per $\mathrm{mg}$ protein under the conditions of the assay.

Values are means \pm SEM, the numbers in parentheses represent the number of evaluated independent experiments. The mycelia were illuminated with white light at $600 \mathrm{~lx}$ for $10 \mathrm{~min}$ and incubated for additional $30 \mathrm{~min}$ at $30{ }^{\circ} \mathrm{C}$ in the dark before the enzyme extraction. The dark controls were from unilluminated mycelia.

Table 2

Glucan and chitin contents in Trichoderma viride cell walls isolated from mycelia after different times following the illumination

\begin{tabular}{lcc}
\hline \multicolumn{1}{c}{ Cell walls from mycelia } & $\beta$-Glucan & Chitin \\
\hline Kept in the dark (control) & $33.9 \pm 1.5(100)$ & $15.7 \pm 0.8(100)$ \\
\hline $\begin{array}{l}\text { Illuminated, harvest time } \\
\text { (min after illumination) }\end{array}$ & \\
30 & $37.5 \pm 1.6(110.6)$ & $13.9 \pm 1.8(88.5)$ \\
60 & $43.3 \pm 4.8(127.7)$ & $15.9 \pm 0.9(101.2)$ \\
120 & $43.7 \pm 0.8(128.9)$ & $16.2 \pm 2.2(103.2)$ \\
240 & $37.3 \pm 3.7(110.0)$ & $16.0 \pm 2.0(101.9)$ \\
\hline
\end{tabular}

The values are averaged from three independent experiments and are expressed in per cent dry weight SEM. The numbers in parentheses indicate per cent control. 
of illuminated mycelia walls was enhanced by $30-35 \%$ in comparison to the dark control, reaching its maximum about $1-2 \mathrm{~h}$ after the illumination. On the other hand, we found no differences in chitin contents of the walls in spite of the decrease in specific CHS activity after the illumination.

It can be assumed that the observed changes in the activities of cell-wall synthesizing enzymes and in the wall composition reflect the transition of the mycelium from vegetative state to sporulation. As a prelude to formation of conidia, numerous aerial branches are formed on vegetative mycelia during first $4 \mathrm{~h}$ after illumination followed by the formation of conidiophores and finaly of the conidia after 16-24 h [2]. The cell walls of Trichoderma viride contain in average $15-20 \%$ chitin and $25-30 \%$ glucan depending on the mycelial age [1]. It is probable that the aerial branches and conidia-bearing structures have different cell wall composition from that of the vegetative mycelium, however it is difficult to ascertain. From our analyses it appears that the cell walls of the aerial hyphae contain considerably higher proportion of $\beta$-1,3-glucan than vegetative mycelium because we were able to detect the differences in the average chemical composition of the cell walls even from the whole mycelia where the vegetative mycelium was present in prevalent part.

The fact that maximum changes in the activities of both cell-wall polysaccharide synthases were observed only $30 \mathrm{~min}$ after the termination of illumination and did not take place in the presence of cycloheximide allows us to speculate that the activities of both enzymes were not regulated by a rapid on-off mechanism, but rather that the observed changes were result of gradual process depending on protein synthesis and degradation. From this point of view, we may consider the effect of light on the individual cell-wall related enzyme activities only as secondary, being a part of the sporogenesis process triggered by illumination.

\section{ACKNOWLEDGEMENTS}

This research was supported by the grant no. 2/7137/20 from the Slovak Grant Agency for Science (VEGA). We thank Chris Shallow for correcting the English style.

\section{REFERENCES}

1. Benítez, T., Villa, T. G., García-Acha, I. (1975) Chemical and structural differences in mycelia and regeneration walls of Trichoderma viride. Arch. Microbiol. 105, 277-282.

2. Betina, V. (1984) Photoinduced conidiation in Trichoderma viride. Int. J. Microbiol. 2, 55-68.

3. Betina, V., Farkaš, V. (1998) Sporulation and light-induced development in Trichoderma. In: Kubicek, C. P., Harman, G. E. (eds) Trichoderma \& Gliocladium. Basic Biology, Taxonomy and Genetics. Taylor \& Francis, London. Vol. 1, pp. 75-94.

4. Cabib, E., Farkaš, V. (1971) The control of morphogenesis: An enzymatic mechanism for the initiation of septum formation in yeast. Proc. Nat. Acad. Sci. USA 68, 2052-2056.

5. Cabib, E., Bowers, B., Sburlati, A., Silverman, A. J. (1988) Fungal cell wall synthesis: the construction of a biological structure. Microbiol. Sci. 5, 370-375.

6. Cabib, E., Drgoňová, J., Drgoň, T. (1998) Role of small G-proteins in yeast polarization and wall biosynthesis. Annu. Rev. Biochem. 67, 307-333.

7. Davidson, E. A. (1966) Analysis of sugars found in mucopolysaccharides. Meth. Enzymol. 8, 52-60. 
8. Fiema, J. (1983) Some aspects of nitrogen metabolism in Aspergillus giganteus mut. alba. I. Chitin content in the cell walls. Acta Physiol. Plant. 5, 113-121.

9. Herrera-Estrella, L., Ruiz-Herrera, J. (1983) Light response in Phycomyces blakesleeanus: evidence for roles of chitin biosynthesis and breakdown. Exp. Mycol. 7, 362-369.

10. Horwitz, B. A., Gressel, J. (1987) First measurable effects following photoinduction of morphogenesis. In: Senger, H. (ed.) Blue-Light Responses, Phenomena and Occurrence in Plants and Microorganisms. CRC Press, Boca Raton, Florida, pp. 53-70.

11. Jan, Y. N. (1974) Properties and cellular localization of chitin synthetase in Phycomyces blakesleenus. J. Biol. Chem. 249, 1973-1979.

12. Lorito, M., Farkaš, V., Rebuffat, S., Bodo, B., Kubicek, C. P. (1996) Cell wall synthesis is a major target of mycoparasitic antagonism by Trichoderma harzianum. J. Bacteriol. 178, 6382-6385.

13. Lowry, O. H., Rosebrough, N. J., Farr, A. L., Randall, R. J. (1951) Protein measurements with Folin phenol reagent. J. Biol. Chem. 193, 265-275.

14. Mazur, P., Baginski, W. (1996) In vitro activity of $\beta$-1,3-glucan synthase requires the GTP-binding protein Rho1. J. Biol. Chem. 271, 14604-14609.

15. Tu, J. C., Malhotra, K. (1977) The significance of cAMP induced alternation in cellular structure of Phycomyces. Can. J. Microbiol. 23, 378-388. 